ANITA KULAWIAK

Uniwersytet Łódzki, Polska - University of Lodz, Poland

\title{
Postawy przedsiębiorcze młodzieży w najmniejszych miastach regionu tódzkiego
}

\section{Entrepreneurial attitudes of young people in the smallest towns of the Łódź region (Poland)}

Streszczenie: Celem artykułu jest określenie i ocena potencjału przedsiębiorczego młodzieży oraz zwrócenie na tym tle uwagi na bariery, które potencjalnie, w przyszłości, mogą utrudnić młodym ludziom wejście w rolę przedsiębiorcy. Analiza ta opiera się na koncepcji postawy S. Nowaka (1973). W badaniu uwzględniono zatem jej trzy komponenty - poznawczy, emocjonalno-oceniający oraz behawioralny. Artykuł powstał na podstawie analizy literatury przedmiotu oraz badań terenowych $\mathrm{z}$ wykorzystaniem kwestionariusza ankiety. Grupę badawczą stanowiła młodzież szkół średnich z wybranych miast regionu łódzkiego, na terenie których znajduje się przynajmniej jedna publiczna szkoła średnia. Badania ujawniły, że respondentów cechował mocno zbilansowany poziom poszczególnych komponentów postawy, co oznacza, że zarówno poziom ich wiedzy na temat przedsiębiorczości oraz stosunek emocjonalny do tego zjawiska, jak i gotowość do podjęcia własnej aktywności jest na zbilansowanym poziomie. Największą barierą dla pełnego rozwinięcia postaw przedsiębiorczych młodzieży na badanym obszarze pozostaje środowisko lokalne.

Abstract: The aim of the article is to define and assess the entrepreneurial potential of young people and, against that background, to draw attention to barriers that potentially, in the future, may hinder young people from entering the role of entrepreneurs. This analysis is based on the concept of attitude by S. Nowak (1973). Therefore, the study took into account its three components - cognitive, emotional-evaluating and behavioural. The article is based on the analysis of the literature on the subject and field research with the use of a questionnaire. The research group consisted of high school students from selected cities of the Eódź region (Poland) where there is at least one public secondary school. The research revealed that the respondents are characterised by a well-balanced level of the individual components of their attitude, which means that both the level of their knowledge about entrepreneurship, their emotional attitude to this phenomenon, and the willingness to undertake their own activity are at a balanced level. The local environment remains the greatest barrier to the full development of entrepreneurial attitudes of young people in the study area. 
Słowa kluczowe: młodzież szkół średnich; najmniejsze miasta regionu łódzkiego; postawa przedsiębiorcza; przedsiębiorczość

Keywords: entrepreneurial attitude; entrepreneurship; high school students; the smallest towns of the Łódź region

Otrzymano: 23 listopada 2021

Received: 23 November 2021

Zaakceptowano: 16 marca 2021

Accepted: 16 March 2021

\section{Sugerowana cytacja/Suggested citation:}

Kulawiak, A. (2021). Postawy przedsiębiorcze młodzieży w najmniejszych miastach regionu łódzkiego. Przedsiębiorczość - Edukacja [Entrepreneurship - Education], 17(1), 140-152. https://doi. org/ 10.24917/20833296.171.11

\section{Wstęp}

Przedsiębiorczość, niezależnie od sposobu jej definiowania, pełni bardzo ważną funkcję w wielu płaszczyznach życia społeczno-gospodarczego. Powszechnie uważana jest za jeden z najistotniejszych atrybutów rynkowego modelu gospodarowania we współczesnym świecie, ale wielu autorów podkreśla także, że odgrywa kluczową rolę w aktywowaniu wzrostu gospodarczego i tworzeniu impulsów do transformowania struktury gospodarczej oraz pozyskiwania nowych źródeł wzrostu wydajności pracy (Dorocki, Kilar, Rachwał, 2011). W świetle znaczenia, które przypisuje się przedsiębiorczości, inicjowanie i promowanie zachowań przedsiębiorczych stało się kluczowym i zarazem najważniejszym wyzwaniem zarówno na poziomie indywidualnym, jak i lokalnym, regionalnym czy krajowym.

Tworzenie środowiska przedsiębiorczości wymaga jednak spojrzenia na przedsiębiorczość z nieco szerszej niż ekonomiczna perspektywy. Jak zwróciła uwagę M. Mularska-Kucharek, „bycie przedsiębiorczym to nie to samo, co bycie przedsiębiorcą. Oznacza to, że działania promujące i wspierające przedsiębiorczość przyniosą wymierne korzyści, jeśli w założeniach zostanie uwzględniony aspekt nie tylko ekonomiczny, lecz także społeczno-psychologiczny" (2016: 166). Na szczególną rolę uwarunkowań psychologiczno-socjologicznych w kreowaniu przedsiębiorczości uwagę zwrócili także I. Sagan, M. Szmytkowska i G. Masik (2009). Autorzy ci słusznie zauważyli, że praktycznie we wszystkich warunkach można zaobserwować lukę pomiędzy różnego typu działaniami władz mającymi na celu pobudzenie przedsiębiorczości a faktycznym odzewem członków społeczności, do których te działania są adresowane. Ta rozbieżność pomiędzy proprzedsiębiorczą polityką a faktycznym zachowaniem aktorów na rynku może być w pełni zinterpretowana jedynie z wykorzystaniem wiedzy na temat psychologicznych uwarunkowań osobowości potencjalnego przedsiębiorcy.

W nawiązaniu do powyższych rozważań niniejszy artykuł podejmuje problematykę przedsiębiorczości, ale w jej społecznym aspekcie. W szczególności, skupiono się w nim na poznaniu cech składających się na postawę przedsiębiorczą młodzieży pochodzącej z wybranych szkół średnich zlokalizowanych na obszarze województwa łódzkiego. Wybór młodzieży na grupę badawczą nie był przypadkowy i wynikał z faktu, że w świetle badań empirycznych w ostatnim czasie nastąpił wzrost samooceny młodzieży dotyczącej 
postawy przedsiębiorczej, a co za tym idzie - wzrosła jej skłonność do podjęcia w przyszłości pracy na własny rachunek (Borgiasz-Stepaniuk, 2019; Gabała, 2005; Kunasz, 2013). Nie bez wpływu na wybór tej grupy badawczej pozostał także fakt, że postawy przedsiębiorcze stanowią tę cechę zbiorowości ludzkiej, którą można kształtować w drodze edukacji (Borowiec, Rachwał, 2011). Rozpoznanie tych postaw w grupie młodzieży szkolnej stwarza zatem szansę na ich wczesne skorygowanie i zmianę w pożądanym kierunku. W przypadku osób dorosłych, które zakończyły już obowiązkową edukację szkolną, zmiana postaw i nawyków jest utrudniona i wymaga dużo większej samodyscypliny i indywidualnego zaangażowania. Monitorowanie postaw przedsiębiorczych młodzieży wydaje się zatem ważnym aspektem na drodze do budowania wysokiej jakość kapitału społecznego, w tym kreowania zachowań przedsiębiorczych w społeczności lokalnej.

W związku z powyższym, celem artykułu jest identyfikacja postawy przedsiębiorczej młodzieży szkolnej oraz zwrócenie uwagi na jej tle na bariery, które potencjalnie, w przyszłości, mogą utrudnić młodym ludziom wejście w rolę przedsiębiorcy. Artykuł powstał na podstawie literatury przedmiotu oraz badań empirycznych.

W pierwszej części artykułu dokonano przeglądu literatury, w drugiej zaprezentowano wyniki analiz danych pozyskanych podczas ankietyzacji respondentów, a także przedstawiono rekomendacje płynące z przeprowadzonych badań.

\section{Postawa przedsiębiorcza i jej znaczenie w najmniejszych miastach regionu tódzkiego}

Postawa przedsiębiorcza jest jednym z rodzajów postaw, które przejawia człowiek w stosunku do innych rzeczy, zjawisk, instytucji oraz ludzi. W naukach społecznych termin „postawa” definiowany jest jako nabyta i zarazem złożona struktura psychofizyczna wyrażająca stosunek emocjonalny człowieka (pozytywny lub negatywny), a także jego gotowość do określonego zachowania się. Do nauki termin ten wprowadziła psychologia amerykańska, gdzie od początku postawę opisywano, opierając się na trzech komponentach: uczuciach (pozytywnych bądź negatywnych), ocenach i działaniach. Zdaniem psychologów amerykańskich (m.in. D. Krecha i R.S. Crutchfielda), na postawę składały się bowiem procesy motywacyjne, emocjonalne, percepcyjne i poznawcze związane z życiem jednostki.

Postawa przedsiębiorcza w potocznym rozumieniu wyraża stosunek człowieka do szeroko pojmowanego zjawiska przedsiębiorczości. W literaturze przedmiotu najczęściej definiuje się ją jako określony zestaw cech, predyspozycji (poglądy, opinie, odczucia jednostki) sprzyjających twórczemu i aktywnemu dążeniu do ulepszania istniejących stanów rzeczy (Piecuch, 2013) lub gotowość do podejmowania nowych działań albo rozszerzania dotychczasowych, w celu poprawy warunków i jakości życia (Borowiec, Rachwał, 2011; Gabała, 2005; Kickul, Grundy, 2002; Wiatrak, 2003). Współcześnie wiele uwagi poświęca się postawie przedsiębiorczej, uważając ją niejako za remedium na przezwyciężenie niektórych problemów zarówno społecznych, jak i gospodarczych. W obecnej sytuacji kreowanie i wspieranie rozwoju przedsiębiorczości jest szczególnie istotne i pożądane w najmniejszych jednostkach osadniczych. Wynika to $\mathrm{z}$ faktu, że w obliczu globalizacji oraz postępującej metropolizacji wiele spośród nich utraciło swoje tradycyjne funkcje lokalne, pełnione na rzecz otaczających je obszarów wiejskich, lub też wyspecjalizowane funkcje usługowe (Korcelli, 2008). Sytuacja ta spowodowała, że małe miasta znalazły się 
Rycina 1. Położenie miast o liczbie ludności do 5 tys. mieszkańców na tle województwa łódzkiego

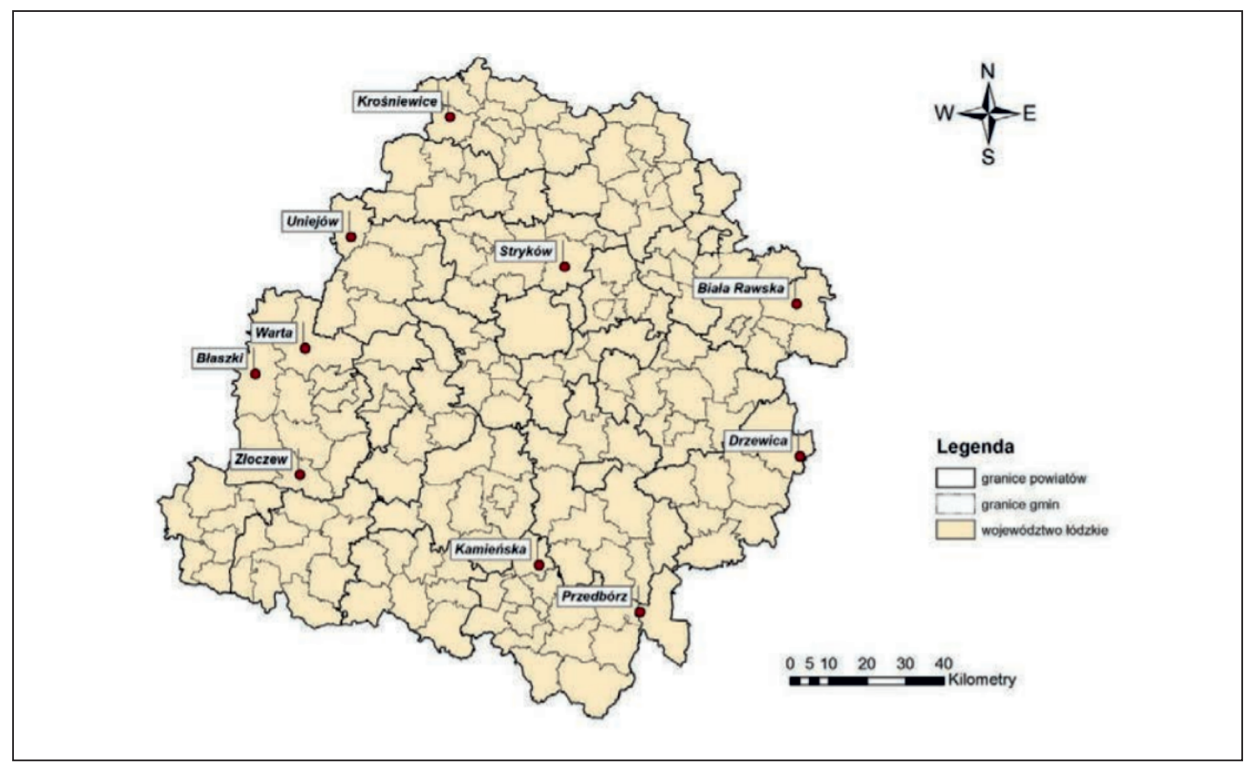

Źródło: opracowanie własne

w trudnej sytuacji społeczno-gospodarczej. Dla wielu z nich postawienie na rozwój przedsiębiorczości jest zatem szansą na zażegnanie lub przynajmniej złagodzenie negatywnych skutków ich załamania gospodarczego. W takiej sytuacji znalazły się m.in. najmniejsze miasta regionu łódzkiego, za które arbitralnie uznano jednostki liczące do 5 tys. mieszkańców. W sumie na obszarze regionu łódzkiego znajduje się 10 miast o liczbie mieszkańców nieprzekraczającej 5 tys. (rycina 1). Stanowią one łącznie 23\% ogólnej liczby miast województwa łódzkiego i koncentrują nieznacznie ponad 2\% ogólnej liczby mieszkańców regionu. Miasta te, poza podobną liczbą ludności, cechuje także, z racji położenia w województwie o silnych tradycjach włókienniczych i wyraźnej dominacji stolicy województwa Łodzi, zbliżona geneza oraz w większości peryferyjne położenie na obrzeżach regionu, jednak w stosunkowo niedalekiej odległości (do $20 \mathrm{~km}$ ) od miast powiatowych. Wszystkie z nich administracyjnie stanowią siedzibę gminy miejsko-wiejskiej. Ponadto cechuje je podobna sytuacja pod względem społecznym i gospodarczym. We wszystkich tych miastach na przestrzeni ostatnich 10 lat odnotowano wyraźny spadek liczby ludności. Wszystkie one należą też do ośrodków starzejących się i o ujemnym saldzie migracji. Pod względem gospodarczym spełniają rolę przede wszystkim lokalnych ośrodków organizujących życie społeczno-gospodarcze społeczności wiejskich (Kulawiak, 2016; Suliborski, Walkiewicz, 2009). We wszystkich z nich podstawę struktury gospodarczej stanowi sektor usług oparty głównie na działalności handlowej, a w mniejszym stopniu - na transporcie i spedycji. W strukturze własności podmiotów gospodarczych wyraźnie dominują firmy prywatne, w tym osób fizycznych, których udział w każdym z omawianych miast wynosi ponad 90\% (Kulawiak, 2016). Dane te wskazują na to, że lokalna przedsiębiorczość stanowi bardzo ważne źródło utrzymania miejscowej ludności. Tym samym zasadne wydaje się nie tylko podejmowanie działań wspierających istniejącą już przedsiębiorczość, ale także rozwijających chęci podejmowania takich zachowań wśród młodszego pokolenia. 
Jest to tym ważniejsze, że w świetle literatury przedmiotu na decyzję o wejściu w rolę przedsiębiorcy w jednakowym stopniu wpływają zarówno uwarunkowania wewnętrzne (endogeniczne), związane $\mathrm{z}$ wrodzonym potencjałem intelektualnym i wychowaniem, jak i uwarunkowania zewnętrzne (egzogeniczne), związane z otoczeniem społeczno-gospodarczym (Czapliński, Kibych, 2017). Oznacza to, iż odpowiednie działania podjęte na gruncie środowiska lokalnego (np. w ramach zajęć szkolnych) mogą zniwelować braki wynikające $z$ cech psychofizycznych jednostki.

\section{Założenia metodyczne badań}

W świetle aktualnej literatury przedmiotu badania postaw przedsiębiorczych najczęściej opierają się na dwóch różnych podejściach (koncepcjach badawczych), aczkolwiek oba z nich mają swoje źródło w naukach społecznych (socjologii i psychologii). Z jednej strony badania te prowadzone są na podstawie istniejących już w literaturze skal przedsiębiorczości, przy czym jedną z najczęściej stosowanych jest skala przedsiębiorczości J. Jerschiny (2000), którą pierwotnie wykorzystano w badaniu dotyczącym orientacji na przedsiębiorczość (Mularska-Kucharek, 2016). Z drugiej zaś strony autorzy identyfikują ją na podstawie samooceny respondentów (Eider i in., 2012; Gabała, 2005; Korpysa, 2007; Targalski, Kosała, Pichur, 2008).

W niniejszym artykule wykorzystano drugi z przedstawionych schematów postępowania. W warstwie teoretycznej praca odwołuje się do koncepcji postawy opisanej przez S. Nowaka (1973), zgodnie z którą na postawę człowieka względem określonej cechy, rzeczy, przedmiotu składają się trzy komponenty - poznawczy, emocjonalny oraz behawioralny. Pierwszy komponent obejmuje wiedzę, opinie i poglądy jednostki, drugi - uczucia pozytywne i negatywne, upodobania, uprzedzenia względem przedmiotu postawy, oparte na doświadczeniach jednostki bądź innych, a trzeci - określone reagowanie, zachowanie jednostki względem danego przedmiotu, prowadzące do aktywności, działania (Turowski, 2001).

Empiryczną podstawę pracy stanowiły materiały i informacje zebrane w trakcie badań terenowych przeprowadzonych od października do grudnia 2019 roku we wszystkich publicznych szkołach średnich (liceach i technikach), zlokalizowanych w miastach województwa łódzkiego liczących do 5 tys. mieszkańców. W sumie badaniem objęto 15 szkół średnich, z których 33\% stanowiły technika (łącznie 5 szkół). Badania prowadzono na obszarze 8 miast (tabela 1). Badaną próbę stanowili uczniowie wszystkich klas trzecich, niezależnie od profilu szkoły i klasy, co było podyktowane chęcią zbadania postawy przedsiębiorczej uczniów, którzy ukończyli już kurs w zakresie podstaw przedsiębiorczości. Badanie przeprowadzono metodą wywiadu kwestionariuszowego na grupie 432 uczniów, w tym 56\% stanowiły kobiety.

Kwestionariusz ankiety został podzielony na trzy części, zgodnie z wyróżnionymi powyżej komponentami postawy, w ramach których sformułowano następujące pytania wskaźnikowe:

- komponent poznawczy - Jaki jest wpływ szkoły i najbliższego otoczenia na kształtowanie postaw przedsiębiorczych młodzieży?, Jaką wiedzę mają uczniowie na temat osób przedsiębiorczych oraz czy identyfikują w swoim najbliższym otoczeniu zachowania przedsiębiorcze i przedsiębiorców?

- komponent afektywny (oceniająco-emocjonalny) - Jaki jest stosunek uczniów do wybranych wartości życiowych? Jak uczniowie oceniają cechy osobowościowe 
kolegów i koleżanek oraz jaki jest ich stosunek do przedstawionych charakterystyk osób przedsiębiorczych;

- komponent behawioralny - Jaka jest aktywność edukacyjna uczniów (uczestnictwo w dodatkowych zajęciach), aktywność społeczna (udział w wyborach szkolnych i krajowych) oraz aktywność zawodowa (doświadczenie z pracą zawodową oraz aspiracje edukacyjne i zawodowe)?

Tabela 1. Miasta, w których przeprowadzono badania

\begin{tabular}{|l|c|}
\hline \multicolumn{1}{|c|}{ Miasto } & $\begin{array}{c}\text { Liczba mieszkańców } \\
\text { (w tys.) }\end{array}$ \\
\hline Krośniewice & 4375 \\
\hline Drzewica & 3844 \\
\hline Przedbórz & 3572 \\
\hline Złoczew & 3384 \\
\hline Warta & 3263 \\
\hline Biała Rawska & 3197 \\
\hline Kamieńsk & 2782 \\
\hline Błaszki & 2122 \\
\hline
\end{tabular}

Źródło: opracowanie własne

\section{Wyniki badań}

\section{Charakterystyka komponentu poznawczego}

Analiza ankiet w zakresie komponentu poznawczego ujawniła, że respondenci mają ogólną wiedzę o przedsiębiorczości, potrafią zdefiniować, czym jest przedsiębiorczość oraz określić, kim jest osoba przedsiębiorcza. Ponadto badania ujawniły, że młodzież cechuje się potrzebą posiadania wiedzy i umiejętności przedsiębiorczych. Odpowiedzi na pytania sprawdzające wiedzę respondentów o tym zjawisku pokazały bowiem, że ponad $80 \%$ badanych potrafiło wymienić co najmniej trzy cechy osoby przedsiębiorczej, przy czym najczęściej wymieniano te, które wskazywane są w literaturze przedmiotu, głównie: kreatywność, innowacyjność, otwartość na nowe wyzwania/ zmiany oraz odporność na stres. Nieco większą trudność sprawiło natomiast młodzieży wymienienie umiejętności potrzebnych w działalności przedsiębiorczej. Choć w ankiecie poproszono o wymienienie co najmniej trzech z nich, warunek ten spełniło tylko 23\% osób. Najwięcej osób (66\%) potrafiło natomiast wymienić jedynie dwie z nich. Najczęściej wymieniano takie umiejętności, jak: dokonywanie trafnych wyborów oraz właściwa ocena ryzyka i swoich możliwości. Ponadto, choć już nieco rzadziej, pojawiały się: umiejętność właściwej organizacji czasu oraz szybkiego rozwiązywania problemów (tabela 2).

Badanym nie sprawiło również problemu zdefiniowanie terminu przedsiębiorczość. Wprawdzie ponad połowa respondentów (51\%) zjawisko to utożsamiała jedynie z zakładaniem i prowadzeniem własnego biznesu, ale kolejne $47 \%$ wiązało ją także z cechami charakteru człowieka. Prawie co drugi badany potrafił zatem zdefiniować ten termin zgodnie z obowiązującą we współczesnej nauce koncepcją przedsiębiorczości, w której przybiera ona postać zarówno procesu, jak i atrybutu człowieka. 
Tabela 2. Cechy i umiejętności osoby przedsiębiorczej

\begin{tabular}{|l|l|}
\hline \multicolumn{1}{|c|}{ Cechy osobowościowe } & \multicolumn{1}{c|}{ Umiejętności } \\
\hline gotowość do działania & umiejętność dokonywania trafnych wyborów \\
\hline $\begin{array}{l}\text { zorientowanie na sukces i osiąganie } \\
\text { celów }\end{array}$ & umiejętność do samoorganizacji pracy i czasu \\
\hline otwartość na wyzwania i zmiany & umiejętność logicznego i samodzielnego myślenia \\
\hline skłonność do podejmowania ryzyka & umiejętność wcielania pomysłów w czyn \\
\hline kreatywność, innowacyjność & umiejętność rozwiązywania problemów \\
\hline zaradność & $\begin{array}{l}\text { umiejętność wykorzystywania kapitału społecznego } \\
\text { i współpracy }\end{array}$ \\
\hline optymizm & $\begin{array}{l}\text { umiejętność wczuwania się w sytuację i rozumienia } \\
\text { innych ludzi }\end{array}$ \\
\hline
\end{tabular}

Źródło: opracowanie własne na podstawie badań ankietowych

W świetle badań ankietowych okazało się, że respondenci wiedzę o przedsiębiorczości czerpią głównie ze szkoły. Tylko $10 \%$ z nich dodatkowo wymieniło inne źródła, takie jak: rodzinne doświadczenia (głównie przykład rodziców) czy media. Badani nie uczestniczyli również w żadnych pozalekcyjnych zajęciach poświęconych przedsiębiorczości, co miało jednak związek głównie z brakiem ich wiedzy o miejscach, gdzie takie zajęcia się odbywają ( $52 \% \mathrm{z}$ nich), w mniejszym zaś stopniu z brakiem chęci uczestniczenia w zajęciach dodatkowych (pozaszkolnych) w ogóle (38\%). W kontekście uzyskanych odpowiedzi ciekawych wniosków dostarczyło pytanie o potrzebę posiadania tego typu wiedzy i umiejętności we współczesnym świecie. W ich opinii jest to bowiem jedna $z$ najważniejszych kompetencji, jakie powinien posiadać człowiek. Takie zdanie wyraziło aż 95\% badanych. W świetle uzyskanych odpowiedzi można zatem stwierdzić, że młodzież z najmniejszych miast regionu łódzkiego dostrzega wagę i znaczenie zagadnienia przedsiębiorczości, posiada też podstawową wiedzę na jej temat oraz czuje potrzebę jej rozwijania.

Wiedzę respondentów na temat lokalnej przedsiębiorczości ujawniło także pytanie dotyczące ich poglądów na temat osób, które w ich najbliższym otoczeniu zasługują na miano przedsiębiorczych i zarazem stanowią wzorzec do naśladowania. Ponad połowa uczniów (62\%) dostrzegała bowiem w swoim otoczeniu osoby przedsiębiorcze, przy czym najczęściej były to osoby z najbliższego otoczenia, głównie ich rodzice i/lub ktoś z rodziny - ciocia, wujek (42\%). Jeszcze mniej ankietowanych (21\%) jako przykład takiej osoby wskazywali lokalnego biznesmena - właściciel sklepu lub punktu usługowego. Warto jednak dodać, że co 10 badany uczeń za osoby przedsiębiorcze uważa także swoich rówieśników. Taki rozkład odpowiedzi wskazuje zatem, że środowisko lokalne nie jest pozbawione wzorców, z których młodzież może czerpać inspirację. Stwarza ono również okazję do podglądania zachowań przedsiębiorczych, a tym samym - do ich naśladowania. Nie są to zatem środowiska pozbawione dobrych praktyk.

\section{Charakterystyka komponentu emocjonalno-oceniającego}

O postawie przedsiębiorczej badanych dużo mówi także ich stosunek do różnych aspektów życia. W tym przypadku ankietowanych zapytano o ich stosunek do: ściągania na klasówkach, kupowania prac zaliczeniowych w celu uzyskania lepszej oceny, nielegalnego kopiowania prac z rożnych źródeł, sprzedawania nielegalnych towarów i usług, 
oszukiwania klientów w celu zwiększenia sprzedaży swoich produktów i korzystania z luk prawa w celu zarobienia większej ilości pieniędzy. Przeprowadzona analiza pokazała, że większość respondentów nie akceptowała wyżej wymienionych zachowań. Co ciekawe, niezależnie od wyrażonej oceny niektóre z tych zachowań zostały uznane za zachowania przedsiębiorcze. Najwięcej respondentów za przejaw przedsiębiorczości uznało przede wszystkim: korzystanie z luk prawa, w celu zarobienia większej ilości pieniędzy (54\%), oszukiwanie klientów w celu zwiększenia sprzedaży swoich produktów (41\%) oraz sprzedawanie nielegalnych towarów i usług (20\%). Warto przy tym dodać, że większe przyzwolenie na tego typu zachowania wykazali mężczyźni niż kobiety, co można wytłumaczyć tym, że mężczyźni wykazują większą determinację w realizacji swoich celów i tym samym są w stanie podjąć każde działanie, które im to umożliwi i zapewni, nawet jeżeli jest ono niezgodne z ogólnie przyjętymi normami społecznymi. Akceptacja dla powyższych działań, jak wskazuje literatura, m.in. J. Górniewicz (1996), może mieć różne źródła. Może być ona wynikiem ogólnego kryzysu moralnego, którego cechą jest upadek jednego systemu wartości i zarazem brak wykształcenia, czy akceptacji, innego, alternatywnego systemu. Opracowanie nowych wartości wymaga czasu i doświadczenia, gdyż formowanie się nowego systemu jest procesem długotrwałym i trudnym. W świecie przełomów, pełnym sprzeczności, młodzież czuje się zatem zagubiona i niepewna, co znajduje odzwierciedlenie w wyznawanych przez nią poglądach i opiniach.

Badaną młodzież poproszono także o ustosunkowanie się do przeciwstawnych twierdzeń, z których jedno odzwierciedlało przedsiębiorcze wartości (tabela 3).

Tabela 3. Wykaz twierdzeń wykorzystanych w badaniu ankietowym do identyfikacji wartości przedsiębiorczych młodzieży

\begin{tabular}{|l|l|}
\hline \multicolumn{1}{|c|}{ Twierdzenie } & \multicolumn{1}{c|}{ Twierdzenie przeciwstawne } \\
\hline $\begin{array}{l}\text { zdolność głoszenia własnych poglądów nawet } \\
\text { kosztem urażenia innych osób }\end{array}$ & $\begin{array}{l}\text { dobre relacje z innymi, nawet kosztem } \\
\text { tłumienia własnych opinii }\end{array}$ \\
\hline $\begin{array}{l}\text { możliwość realizacji własnych marzeń, nawet } \\
\text { kosztem wysiłku i stresu }\end{array}$ & $\begin{array}{l}\text { życie bez stresu i ryzyka, nawet kosztem } \\
\text { rezygnacji ze swoich ambicji }\end{array}$ \\
\hline $\begin{array}{l}\text { zmiany, które czynią świat lepszym, nawet jeśli } \\
\text { przebiegają gwałtownie i są bardzo radykalne }\end{array}$ & $\begin{array}{l}\text { stabilność, przewidywalność, przyszłość dająca } \\
\text { tzw. święty spokój }\end{array}$ \\
\hline wykształcenie jako możliwość samorozwoju & $\begin{array}{l}\text { wykształcenie jako „papierek”, formalność } \\
\text { ułatwiająca znalezienie pracy }\end{array}$ \\
\hline
\end{tabular}

Źródło: opracowanie własne na podstawie badań ankietowych

Analiza danych wskazała, że w większości przeważały odpowiedzi ukierunkowane na postawę przedsiębiorczą i indywidualizm. Najwięcej wskazań otrzymały bowiem twierdzenia, które wiążą się z cechami silnie kojarzonymi z przedsiębiorczością: ambicja, samorozwój, zorientowanie na sukces, gotowość do działania, pracowitość. Wartościami, z którymi utożsamiano się najbardziej, były: dążenie do realizacji własnych marzeń nawet kosztem ciężkiej pracy (62\%) oraz wykształcenie jako możliwość samorozwoju (56\%). Ponadto, równie często (42\%) respondenci wybierali: wolność głoszenia własnych poglądów nawet za cenę urażenia innych osób. Wyniki potwierdzają, zaobserwowaną wcześniej w społeczeństwie polskim, tendencję, polegającą na spadku znaczenia umiejętności i chęci współpracy z innymi kosztem wzrostu poziomu indywidualizmu (Boguszewski i in., 2014). 
W ramach identyfikacji afektywnego komponentu postawy przedsiębiorczej poproszono także o wymienienie cech, które badani u rówieśników lubią najlepiej. Pytanie to miało zweryfikować, czy wśród wymienionych cech pojawią się cechy kojarzone z przedsiębiorczością. Jak wynika $\mathrm{z}$ badań, ludzie preferują oraz szukają u innych cech podobnych do swoich. Założono zatem, że wskazania badanych mogą pośrednio ujawnić cechy, które oni sami posiadają. Analiza odpowiedzi ujawniła ciekawą tendencję. Respondenci u swoich rówieśników w niemal jednakowym stopniu preferowali cechy, które powszechnie przypisywane są przedsiębiorcom (48\%), jak i takie, które nastawione są na drugiego człowieka (52\%). W większości młodzież u swoich rówieśników lubiła bowiem takie cechy, jak: poczucie humoru, koleżeńskość, uczciwość, oddanie. Pozytywnie oceniła także umiejętność samoorganizacji, zorientowanie na sukces, kreatywność i pomysłowość.

W świetle badań tego komponentu postawy przedsiębiorczej można stwierdzić, że młodzież wykazuje pozytywny stosunek zarówno do samego zjawiska, jak i do osób przedsiębiorczych.

\section{Charakterystyka komponentu behawioralnego}

W ramach poznania ostatniego z komponentów postawy w pierwszej kolejności zidentyfikowano aktywność edukacyjną młodzieży, uznając, że podnoszenie kompetencji w procesie uczenia się przez całe życie może zaowocować wieloma korzyściami, nie tylko w obszarze życia zawodowego, ale również - życia osobistego. Cykliczne badania Bilansu Kapitału Ludzkiego (BKL) pokazują, że w 2017 roku odsetek Polaków w wieku 18-64 lata, którzy podnosili swoje kwalifikacje, zarówno w formie edukacji formalnej, jak i nieformalnej, wynosił 37\% i był stały od 2010 roku. W grupie osób młodych, tj. między 18 a 24 rokiem życia, odsetek ten także był mały, gdyż wynosił zaledwie 18\% (Portal PARP, 2020, 12 listopada).

Uzyskane w drodze badań wyniki również potwierdzają tę niekorzystną tendencję, ale zarazem wskazują, że źródło niepodejmowania takiej aktywności nie zawsze leży po stronie ucznia. W grupie badanych udział w zajęciach pozaszkolnych, rozwijających wiedzę i dodatkowe umiejętności, zadeklarowała blisko połowa uczniów (49\%) i najczęściej była to nauka języka obcego (68\% badanych). Na drugim miejscu badani (33\%) wskazali zajęcia sportowe, a na trzecim - (12\%) naukę gry na instrumencie. Warto jednak podkreślić, że osoby, które zadeklarowały brak udziału w zajęciach pozaszkolnych, najczęściej motywowały to brakiem czasu w związku z innymi obowiązkami (42\%), brakiem środków finansowych (25\%) oraz brakiem interesującej oferty takich zajęć (10\%). Rzadko natomiast wśród powodów pojawiały się: lenistwo (12\%) czy brak zainteresowania takimi zajęciami w ogóle (11\%). Wyniki te wskazują, że młodzież ma świadomość ciągłego dokształcania się i poszerzania swojej wiedzy, która to w przyszłości może zaowocować lepiej płatną pracą. Warto zauważyć, że deklarowane przez uczniów stanowisko jest spójne z wyrażoną przez nich opinią dotyczącą zorientowania na osiągnięcie celów kosztem ciężkiej pracy.

W ramach identyfikacji komponentu behawioralnego zapytano także młodzież o jej aspiracje edukacyjne. Badania ujawniły ciekawe spostrzeżenie. Otóż z jednej strony respondenci deklarowali chęć kontynuowania nauki w szkole wyższej (69\% z nich), a $\mathrm{z}$ drugiej strony preferowali kierunki powszechnie uważane za łatwiejsze, takie jak: socjologia, psychologia, gospodarka przestrzenna i pedagogika (łącznie 59\%), rzadziej zaś kierunki ekonomiczne, prawnicze czy politechniczne (39\%). Taki rozkład odpowiedzi 
wskazuje, że młodzież nie jest pozbawiona aspiracji, ale zarazem cechuje ją słabszy niż młodzież z dużych miast poziom samooceny i poczucia pewności siebie. W opinii tych młodych ludzi edukacja w ośrodkach lokalnych wciąż bowiem jest gorsza aniżeli ta $\mathrm{w}$ największych miastach. Dlatego też młodzi z najmniejszych ośrodków wybierają raczej te uczelnie, na które łatwiej się dostać. W kontekście postawy przedsiębiorczej pozytywnym aspektem jest jednak to, że uczniowie wykazują chęć dalszego rozwijania swojej wiedzy, a co za tym idzie - podnoszenia swoich kompetencji i umiejętności. Jako grupę w większości cechuje ich zatem aktywność społeczna. To, że przejawiają aktywną postawę, potwierdziło również pytanie o ich aspiracje i plany związane z przyszłą karierą zawodową. Analiza odpowiedzi na nie ujawniła, że choć w grupie dominują osoby, które marzą o pracy na etacie (58\%), najlepiej w administracji samorządowej lub firmie prywatnej, to jednak znaczny odsetek stanowią też ci, którzy planują otworzyć własny biznes (40\%). Pozostałe 2\% nie chciało ujawnić swoich planów. Warto zatem podkreślić, że choć ukończenie studiów wyższych w opinii badanych nie zawsze idzie w parze z uzyskaniem satysfakcjonującej i dobrze płatnej pracy, to jednak nie zamierzają oni pogodzić się z gorszymi warunkami życia. W świetle badań deklarowana chęć założenia własnej firmy jest bowiem wynikiem chęci zarobienia większej ilości pieniędzy (54\%), zapewnienia sobie wyższego niż dotychczas poziomu życia (25\%), realizacji marzeń (12\%) i w końcu - osiągnięcia niezależności (7\%).

Badania ujawniły również, że młodzież z regionu łódzkiego cechuje znaczna aktywność społeczna i zawodowa. Pracę na rzecz społeczności (zaangażowanie w samorządzie szkolnym, wolontariacie itp.) zadeklarowało bowiem $48 \%$ badanych. Ponadto niemal 37\% przyznało, że ma już pierwsze doświadczenia zawodowe. Najwięcej osób pomagało rodzicom w prowadzeniu własnego biznesu (78\%), pozostałe osoby zadeklarowały prace dorywcze w postaci pomocy dziadkom podczas żniw czy w restauracji w czasie wakacji. Badania wskazały, że już od najmłodszych lat respondenci mają szansę nabyć cechy pożądane dla osoby przedsiębiorczej, czyli: pracowitość, punktualność, odporność na stres, umiejętność organizacji czasu pracy, szacunek do pieniądza. Tym samym w swoim najbliższym otoczeniu mogą też kształtować w sobie tak pożądaną współcześnie postawę przedsiębiorczą.

\section{Wnioski i rekomendacje}

Celem artykułu była identyfikacja i ocena postawy przedsiębiorczej młodzieży pochodzącej z najmniejszych miast regionu łódzkiego oraz określenie na tym tle barier utrudniających wejście w rolę przedsiębiorcy. Analiza danych dotyczących wyróżnionych komponentów postawy pozwoliła na skonstruowanie wskaźników syntetycznych (indexów) wyrażających poziom każdego z nich w postaci wartości liczbowej, znajdującej się w przedziale od 0 do 1, gdzie 0 oznacza niski poziom danego komponentu, a wartość 1 wysoki poziom. Syntetyczny indeks każdego komponentu uzyskano przez zsumowanie wartości wybranych pytań wskaźnikowych. Celem uzyskania porównywalnych wyników z każdego komponentu wybrano po trzy pytania. Przyjęta procedura ujawniła, że średnie wartości wszystkich komponentów postawy przedsiębiorczej w badanej populacji wykazały podobną wielkość i oscylowały na średnim poziomie. Najniższą średnią wartość uzyskał komponent poznawczy - 0,45, a najwyższą - 0,68 - komponent emocjonalno-oceniający. Trzecia z wyróżnionych kategorii - komponent behawioralny - uzyskała wartość 0,51 . 
Przyjęta metoda syntetyzacji wyników, choć mocno zgeneralizowana, pozwala jednak stwierdzić, że badaną grupę cechował bardzo zbilansowany poziom poszczególnych komponentów postawy. Brak wyraźnej dominacji jednego z nich oznacza, że zarówno poziom ich wiedzy na temat przedsiębiorczości, stosunek emocjonalny do tego zjawiska, jak i gotowość do podjęcia własnej aktywności jest na zbilansowanym poziomie. Znajduje to również odzwierciedlenie w wartości średniej poziomu indeksdu postawy przedsiębiorczej uwzględniającej łącznie wszystkie wyróżnione w badaniach komponenty, który wyniósł 0,55. W świetle badań, respondentów cechuje przeciętny poziom postawy przedsiębiorczej, aczkolwiek posiadają oni predyspozycje i potencjał do wykształcenia w sobie wysokiego poziomu postawy przedsiębiorczej. Przede wszystkim wyraża się to w ich pozytywnym nastawieniu do zjawiska przedsiębiorczości, dostrzeganiu w swoim otoczeniu osób przedsiębiorczych, czy też w deklarowanej dość powszechnie aktywności społecznej zarówno na forum szkolnym, jak i poza szkołą. Badania wskazują także, że dla osiągnięcia zamierzonych celów są oni w stanie wskrzesić w sobie energię do działania. Biorąc pod uwagę fakt, że w świetle literatury przedmiotu postawę przedsiębiorczą kształtują czynniki dwojakiego rodzaju - wewnętrzne, związane $\mathrm{z}$ wrodzonym potencjałem intelektualnym, który może być wzmocniony dzięki odpowiednim działaniom wychowawczym, oraz zewnętrzne, których źródłem jest otoczenie społeczno-ekonomiczne, można stwierdzić, że większą barierą blokującą działania przedsiębiorcze młodzieży stanowią głównie drugie z nich. Chodzi tu przede wszystkim o brak aktywności środowiska lokalnego, w tym władz lokalnych, na rzecz budowania zainteresowania tym zagadnieniem oraz realnego promowania tego typu zachowań, np. przez organizowanie zajęć pozaszkolnych rozwijających umiejętności przedsiębiorcze, czy też organizowanie spotkań z lokalnymi biznesmenami lub z osobami znanymi i aktywnymi w lokalnym środowisku. Przeprowadzona $\mathrm{w}$ trakcie badań terenowych kwerenda pozwoliła zauważyć, że w żadnym $\mathrm{z}$ badanych miast nie podejmuje się żadnych z wyróżnionych powyżej działań. Warto dodać, iż zaobserwowany w grupie respondentów poziom postawy przedsiębiorczej zasadniczo nie odbiega od poziomu postawy reprezentowanej przez młodzież z innych polskich miast. Wprawdzie prowadzone w tym zakresie badania dotyczyły głównie studentów, rzadziej młodzieży szkół średnich, niemniej jednak również ujawniły one średni potencjał postaw przedsiębiorczych (Borgiasz-Stepaniuk, 2019; Gabała, 2005; Płaziak, Rachwał, 2014; Pichur, Kosała, 2008; Wach, Rachwał, 2016). Po części wskazuje to zatem na małe znaczenie wskazywanego przez niektórych badaczy czynnika kulturowego w kreowaniu postaw przedsiębiorczych. Badani pochodzili bowiem $z$ różnych stron Polski i niezależnie od miejsca pochodzenia wyróżniała ich duża skłonność do zakładania w przyszłości własnego biznesu, ale zarazem mała wiara we własne możliwości. Pośrednio przeprowadzone badania wskazały także na konieczność stałego monitorowania postaw przedsiębiorczych. Systematyczna identyfikacja postaw społeczności względem zjawiska przedsiębiorczości może być bowiem bardzo pomocna w ich właściwym kształtowaniu. Warto mieć to na uwadze tym bardziej, że w świetle najnowszych badań, zdolność człowieka do kreatywnego myślenia, w tym również do zachowań przedsiębiorczych, tylko w 1/3 uwarunkowana jest odpowiednimi genami. Pozostała część to wynik procesu uczenia się (analizy, zrozumienia własnych umiejętności, ich praktykowania, eksperymentowania, zdobywania zaufania do swoich zdolności itp.) (Danilewicz, 2014), a także bodźców płynących $\mathrm{z}$ otoczenia. 
Literatura

References

Boguszewski, R., Feliksiak, M., Gwiazda, M., Kalka, J. (2014). Młodzież o sobie: wartości, obyczajowość, grupy odniesienia. W: Młodzież 2013. Warszawa: CBOS, 106-153.

Borgiasz-Stepaniuk, M. (2019). Postawy przedsiębiorcze wśród młodzieży. Przedsiębiorczość - Edukacja [Entrepreneurship - Education], 15(1), 47-60.

Borowiec, M., Rachwał, T. (2011). Kształtowanie postaw przedsiębiorczych na lekcjach geografii wyzwaniem edukacyjnym w procesach globalizacji. Przedsiębiorczość - Edukacja [Entrepreneurship - Education], 7, 321-332.

Czapliński, P., Kibych, I. (2017). Postawy abiturientów wobec rynku pracy. Szczecin i Czerniowice studium przypadku. Przedsiębiorczość - Edukacja [Entrepreneurship - Education], 13, 405-416.

Danilewicz, D. (2021). Wewnętrzne i zewnętrzne determinanty kształtujące postawę przedsiębiorczą. W: A. Postuła, B. Glinka, J. Pasieczny (red.), Oblicza przedsiębiorczości. Warszawa: Wydawnictwo Naukowe Wydziału Zarządzania Uniwersytetu Warszawskiego.

Dorocki, S., Kilar, W., Rachwał, T. (2011). Założenia i cele Projektu „Krok w przedsiębiorczość” dla nauczycieli szkół ponadgimnazjalnych. Przedsiębiorczość - Edukacja [Entrepreneurship Education], 7, 308-320.

Eider, J., Sieńko-Awierianow, E., Stępień-Słodkowska, M. (2012). Postawy przedsiębiorcze studentów. Zeszyty Naukowe Uniwersytetu Szczecińskiego. Ekonomiczne Problemy Usług, 2(98), 37-49.

Gabała, J. (2005). Kształtowanie postaw przedsiębiorczych uczniów. Przedsiębiorczość - Edukacja [Entrepreneurship - Education], 1, 145-152.

Gibb, A.A. (1993). Enterprise Culture and Education: Understanding Enterprise Education and Its Links with Small Business, Entrepreneurship and Wider Educational Goals. International Small Business Journal, 11(3), 11-34.

Górniewicz, J. (1996). Teoria wychowania. Wybrane problemy. Toruń-Olsztyn: SKU, Glob.

Jerschina, J. (2000). Postawy przedsiębiorczości w Polsce na tle krajów Europy Środkowej i Wschodniej. Elity i społeczeństwa (kontynuacja). Przegląd Socjologiczny, 49(1).

Kickul, J., Grundy, L. (2002). Prospecting for Strategic Advantage: The Proactive Entrepreneurial Personality and Small Firm Innovation. Journal of Small Business Management, 40, 85-97.

Korcelli, P. (2008). System osadniczy Polski - tendencje i uwarunkowania przemian. Studia KPZK, 31, $30-42$.

Korpysa, J. (2007). Uwarunkowania przedsiębiorczości studentów - rezultaty badań. W: D. Kopycińska (red.), Wykorzystanie zasobów pracy we współczesnej gospodarce. Szczecin: Wydawnictwo Naukowe Katedry Mikroekonomii Uniwersytetu Szczecińskiego, 228-236.

Kulawiak, A. (2016). Przedsiębiorczość w najmniejszych miastach regionu łódzkiego. Annales Universitatis Paedagogicae Cracoviensis. Studia Geographica, 10, 153-165.

Kunasz, M. (2013). Determinanty przedsiębiorczości w gospodarkach unijnych. Szczecin: Volumina.

Mularska-Kucharek, M. (2016). Społeczne uwarunkowania postaw przedsiębiorczych. Edukacja Ekonomistów i Menadżerów, 3(41), 165-177.

Nowak, S. (1973). Wstęp. W: S. Nowak (red.), Teorie postaw. Warszawa: Państwowe Wydawnictwo Naukowe.

Piecuch, T. (2013). Przedsiębiorczość. Podstawy teoretyczne. Warszawa: C.H. Beck.

Pichur, A., Kosała, M. (2008). Powstawanie oporów wobec innowacji oraz sposoby ich przełamywania w zarządzaniu przedsiębiorstwem. Zeszyty Naukowe. Uniwersytet Ekonomiczny w Krakowie, 799, $87-98$.

Płaziak, M., Rachwał, T. (2014). Kształcenie w zakresie przedsiębiorczości w polskich uniwersytetach na studiach nieekonomicznych (na przykładzie kierunku geografia). Horyzonty Wychowania, 13(26), 249-266.

Portal PARP. (2020, 12 listopada). https://www.parp.gov.pl 
Postawy przedsiębiorcze a strategia lizbońska. (2008; 2020, 11 listopada). http://eur-lex.europa.eu/ LexUriServ/LexUri

Sagan, I., Szmytkowska, M., Masik, G. (2009). Postawy przedsiębiorcze mieszkańców Gdyni. Przedsiębiorczość - Edukacja [Entrepreneurship - Education], 5, 229-243.

Suliborski, A., Walkiewicz, D., (2009). Współczesne zróżnicowanie społeczno-gospodarcze województwa łódzkiego. W: K. Badziak, M. Łapa (red.), Województwo łódzkie 1919-2009. Studia i materiaty. Łódź: Polskie Towarzystwo Historyczne, 243-250.

Targalski, J., Kosała, M., Pichur, A. (2007). Postawy przedsiębiorcze wśród studentów kierunku ekonomia Akademii Ekonomicznej w Krakowie. Analiza wyników badań. W: P. Wachowiak, M. Dąbrowski, B. Majewski (red.), Kształtowanie postaw przedsiębiorczych a edukacja ekonomiczna. Warszawa: Fundacja Promocji i Akredytacji Kierunków Ekonomicznych.

Turowski, J. (2001). Socjologia. Małe struktury społeczne. Lublin: Towarzystwo Naukowe Katolickiego Uniwersytetu Lubelskiego.

Wach, K., Rachwał, T. (2016), Badanie intencji przedsiębiorczych młodego pokolenia: wyniki ankietyzacji wśród studentów kierunków nieekonomicznych. Przedsiębiorczość - Edukacja [Entrepreneurship - Education], 12, 229-243.

Wiatrak, A.P.(2003). Pojęcie przedsiębiorczości, jej cele i rodzaje. W: K. Jaremczuk(red.), Uwarunkowania rozwoju przedsiębiorczości - szanse i zagrożenia. Tarnobrzeg: PWSZ, 26-38.

Anita Kulawiak, dr, adiunkt Uniwersytetu Łódzkiego, zatrudniona w Katedrze Geografii Regionalnej i Społecznej. Zainteresowania badawcze autorki oscylują wokół wielu problemów związanych z szeroko rozumianą geografią społeczną oraz regionalną i dotyczą problematyki przedsiębiorczości zarówno od strony procesualnej (zakładania i prowadzenia działalności gospodarczej, jej rozmieszczenia), jak i atrybutywnej - rozumianej jako cecha ludzka. W tym przypadku przedmiotem zainteresowania autorki są postawy przedsiębiorcze oraz motywy podejmowania własnej inicjatywy gospodarczej.

Anita Kulawiak, PhD, assistant professor at the University of Lodz, employed in the Department of Regional and Social Geography. The author's research interests oscillate around many problems related to broadly understood social and regional geography. First of all, they relate to the issues of entrepreneurship both in terms of processes (establishing and running a business), its spatial diversity and factors determining its distribution, but also attributive entrepreneurship understood as a human trait. In this case, the author is interested in entrepreneurial attitudes and motives for starting one's own economic initiative. Apart from the issues of entrepreneurship, the author's works also oscillate around issues related to the city's public space, market squares and territorial identity.

ORCID: https://orcid.org/0000-0002-7458-0330

\section{Adres/Address:}

Uniwersytet Łódzki

Katedra Geografii Regionalnej i Społecznej

ul. Kopcińskiego 31

90-142 Łódź, Poland

e-mail: anita.kulawiak@geo.uni.lodz.pl 